\title{
Redaksioneel
}

\section{Innovasie - die hefboom vir tegnologie- gebaseerde welvaartskepping}

\begin{abstract}
Ekonomiese groei is noodsaaklik ten einde te kan voortbou op die momentum van die nuwe demokrasie in Suid-Afrika. Die mikpunte van die Heropbou-en Ontwikkelingsprogram (HOP) moet egter nagestreef word in ' $n$ tyd waarin nie net Suid-Afrika nie, maarook die res van die wêreld, hulself in 'n omgewing bevind waar vinnige verandering die norm is. Met die beëindiging van die Koue Oorlog het die militêre Oos-Wes-spanning van die laaste vyftig jaar afgeneem, maar terselfdertyd het die bestaan van 'n globale ekonomiese oorlog baie prominent geword. Dit is duidelik dat daar in die nuwe eeu volgens nuwe reëls gespeel gaan word en dat sukses in 'n groot mate bepaal gaan word deur 'n land se vermoë om internasionaal mee te ding. Oor die algemeen beskou, is mededingendheid die vermoë van 'n land om goedere en dienste te produseer wat die toets van internasionale kompetisie kan weerstaan, terwyl 'n volgehoue toename in die lewenskwaliteit van die land se burgers teweeggebring word, oftewel, die land se vermoë om welvaart te skep in 'n kompeterende omgewing. Die strategiese aanwending van tegnologie gaan sonder twyfel een van die belangrikste faktore in die strewe na internasionale mededingendheid en die skep van nasionale welvaart wees.

Die term "tegnologie" is baie omvattend en menige interpretasie en definisie is al daaraan toegedig. Die belangrikste vraag wat egter ontstaan, is volgens watter spesifieke meganismes tegnologie aangewend kan word om mededingendheid te bereik. Die hefboom waarmee dit gedoen kan word, is dieproses van tegnologiese innovasie. Daar word algemeen aanvaar dat ' $n$ land se mededingendheid afhang van die vermoë van sy nywerhede om te innoveer.
\end{abstract}

\section{Wat is innovasie?}

Innovasie word dikwels verwar met 'n paar verwante konsepte soos kreatiwiteit, uitvinding, ontdekking, vernuftigheid en entrepreneurskap. Dit is derhalwe toepaslik om die verskille uit te klaar alvorens innovasie van nader beskou word. Kreatiwiteit is een van die meganismes waarmee idees verkry kan word, spesifiek die vermoë om self idees op te wek. Daar is egterook vele ander maniere om idees te bekom. So byvoorbeeld kan idees gekoop, geleen, gehuur of gesteel word. Sommige van hierdie maniere mag miskien immoreel of onwettig wees, maar hulle is steeds geldig. Idees lei weer op hulle beurt na uitvindings.

'n Uitvinding is in wese die skep van 'n nuwe produk, proses of diens. Daar is ' $n$ denkrigting wat meen dat die uitvinding eintlik vergestalt is in informasie, en daarom baie klem op die idee agter die uitvinding lê. 'n Ander gedagtegang is dat die tegniese lewensvatbaarheid gedemonstreer moet word om 'n uitvinding van 'n idee te onderskei.' $n$ Uitvinding kan natuurlik ook uit' $n$ kombinasie van ander idees en ander uitvindings bestaan, hetsy nuut of nie. Die belangrike punt is egter dat die kriterium vir sukses van ' $n$ uitvinding ' $n$ tegniese een is - of die nuwe uitvinding werk of dit werk nie. Patente word vir uitvindings toegestaan op grond van hulle tegniese eienskappe.

Waar ' $n$ uitvinding ' $n$ geskepte vermoë is, is ' $n$ ontdekking die bewuswording van 'n bestaande verskynsel. Vernuftigheid het te make met die vindingryke aanwending van ' $n$ idee of tegniek. Entrepreneurskap is in wese die stig van nuwe besigheidsondernemings. Sulke nuwe inisiatiewe kan natuurlik ook binne bestaande organisasies geskep word, in welke geval soms daarna verwys word as intrepreneurskap. Alhoewel al hierdie konsepte op een of ander manier verwant is aan innovasie. is nie een van hulle innovasie per se nie.

Tegnologiese innovasie is 'n omvattende proses wat die aksies insluit wat tot uitvinding lei (insluitend die verkryging van idees, navorsing en ontwikkeling), asook al die stappe wat tot kommersialisering aanlei. Soms word daar ook na die resultaat van hierdie proses verwys as "die innovasie". Innovasie het te make met die skep van nuwe produkte, prosesse, dienste en tegnieke asook hulle aanvaarding in die mark. Dit is belangrik om te besef dat daar twee komponente in die innovasieproses aanwesig is, naamlik 'n uitvindingskomponent en 'n aanvaardingskomponent (anders as in die geval van 'n uitvinding waar slegs die eerste komponent teenwoordig is). Aanvaarding in die mark sal in die geval van 'n kommersiële produk gewoonlik impliseer dat 'n groot aantal verbruikers die produk gekoop het. Indien 'n produk nie deur dic mark aanvaar word nie, bly dit net 'n uitvinding. Die kriterium van sukses van 'n innovasie is dus 'n kommersiële een, in teenstelling met die kriterium van sukses van 'n uitvinding wat ' $n$ tegniese een is. Daar is talle voorbeelde van produkte wat tegnies baie geslaagd was, maar glad nie deur die mark aanvaar is nie en derhalwe kommersieel gefaal het. Dink maar aan die Ford Edsel, die destydse videotelefoon, videoplate en die wankelenjin. Waar uitvindings nuwe kennis skep, skep innovasie nuwe welvaart - en dit is tog immers wat nou belangrik is.

\section{Die aard van innovasie}

Innovasies hoef natuurlik nie noodwendig net tegnies van aard te wees nie. 'n Nuwe tipe polis van 'n versekeringsmaatskappy kan byvoorbeeld 'n finansiële innovasie wees, die konsep van selfbediening 'n diensinnovasie en demokrasie 'n administratiewe innovasie. In al hierdie gevalle impliseer innovasie dus 'n uitvinding sowel as aanvaarding in die mark. In die geval van tegnologiese innovasies kan daar verder onderskei word tussen produk- en prosesinnovasies, asook tussen 
radikale en inkrementele innovasies. Onderproses word verstaan die proses waarmee die produk vervaardig word. In die geval van 'n prosesinnovasie sal aanvaarding in die mark nie noodwendig impliseer dat baie verbruikers die produk moes koop nie. Aanvaarding sal hier dus eerder impliseer dat die innovasie wel suksesvol gebruik word. Radikale innovasies, wat produk- of prosesinnovasies kan wees, berus gewoonlik op 'n totaal nuwe konsep of benadering wat ' $n$ toename van ten minste 'n ordegrootte of meer in een of ander prestasiekenmerk teweegbring, en wel van so 'n aard dat geen toename in skaal, effektiwiteit of ontwerp van die vorige tegnologie daarby kan kers vashou nie. Hier dink 'n mens byvoorbeeld aan straalmotore wat skroefmotore in vliegtuie vervang het, optiese veselkabels wat koperkabels vir telekommunikasiekanale vervang, of kwartskristalle wat meganiese vere in horlosies vervang het. Inkrementele innovasies, aan die ander kant, is gewoonlik klein en kontinue verbeterings wat deur menige individu wat normaalweg geografies versprei is, oor' $n$ relatiewe lang tydperk gemaak word. Alhoewel elke klein verbetering gewoonlik nie' n noemenswaardige effek het nie, is die kumulatiewe effek van inkrementele innovasie oor ' $n$ lang tydperk soms baie dramaties. Dit is belangrik om te besef dat een tipe innovasie, hetsy dit 'n produk- of prosesinnovasie, of ' $n$ radikale of inkrementele innovasie is, nie inherent belangriker is as ' $n$ ander een nie. Elke tipe innovasie is potensieel belangrik, maar elkeen het sy plek in die innovasieketting. Die uitdaging is om die innovasieproses te bestuur deur op die regte tydstip op die regte tipe innovasie die klem te plaas en uiteindelik nuwe idees in markvoordeel te omskep.

\section{Die vloedgolf van kreatiewe vernietiging}

Die ekonoom Joseph Schumpeter het innovasie beskryf as 'n "vloedgolf van kreatiewe vernietiging", waarmee hy te kenne wou gee dat innovasie nie alleen nuwe tegnologieë, produkte en industrieë skep nie, maar terselfdertyd die ondergang van die oues teweegbring. In ons leeftyd het totaal nuwe industrieë ontstaan rondom die ontwikkeling van mikroëlektronika, biotegnologie, rekenaars en vliegtuie. Aan die ander kant het nuwe innovasie gevestigde industrieë soos seilskepe, perdekarre, blokkiesvloere en langspeelplate laat kwyn tot waar hulle heeltemal verdwyn het of slegs baie klein nismarkte bedien. Die dinamika van tegnologiese verandering en vernuwing is die hart van tegnologiese innovasie, en die vermoë om die tegnologiese toekoms te antisipeer en sodoende tegnologiese bedreigings en geleenthede te identifiseer en dan daarop te reageer, is die bron van ' $n$ wenvoorsprong. Ten einde die proses van tegnologiese innovasie suksesvol te implementeer, is dit egter nodig om nie alleen aan die tegnologiese aspekte aandag te gee nie. Die mark speel uiteraard ' $n$ uiters belangrike rol, hetsy of die innovasie mark- of tegnologiegedrewe is. Sonder suksesvolle kommersialisering is die stryd net half gewonne.

\section{Bestuur van innovasie}

Aangesien tegnologiese innovasie een van die belangrikste sleutels tot die skep van nasionale welvaart is, ontstaan die vraag of dit in beginsel enigsins moontlik is om die proses van tegnologiese innovasie formeel te bestuur. Die antwoord is sonder twyfelja! Die bestuur van tegnologiese innovasie vind beslag in 'n nuwe dissipline wat as tegnologiebestuur bekend staan. Alhoewel dit 'n relatiewe jong dissipline is, is dit groeiend en dinamies van aard en word dit toenemend in die bedryf toegepas, en geniet ook in 'n toenemende mate formeel in die akademie aandag.

Nie alleen kan tegnologiese innovasie bestuur word nie, maar soos die tempo van tegnologiese verandering toeneem en tegnologiese stelsels in kompleksiteit, koste en risiko eskaleer, word die noodsaaklikheid van 'n formele benadering tot tegnologiebestuur en spesifiek die bestuur van tegnologiese innovasie al belangriker - op die firmavlak sowel as op nasionale vlak. In beleidskringe is die ontwikkeling en bestuur van die nasionale innovasiestelsel tans een van dié onderwerpe van bespreking. Skeptici kan uiteraard na vele suksesvolle tegnologiese innovasies wys waar daar weinig sprake van formele tegnologiebestuur was, en waar die sukses aan geluk, intuïsie en algemene bestuursvaardighede of ' $n$ kombinasie daarvan te danke was. Daar bestaan egter geen twyfel nie dat daar met so 'n strategie (of eintlik gebrek aan strategie) baie meer mislukkings as suksesse is. Soos ondernemings hulle personeel-, bemarkings- en finansiële funksies formeel bestuur, is dit noodsaaklik dat tegnologie ook voortaan formeel bestuur moet word. 'n Ad hoc- en arbitrêre benadering tot tegnologiebestuur, en spesifiek die bestuur van tegnologiese innovasie, is net nie meer goed genoeg nie.

Tegnologiese innovasie is die hefboom vir tegnologiegebaseerde welvaartskepping, en as sulks moet dit doelgerig en aggresief bestuur word ten einde Suid-Afrika in staat te stel om mededingend in die internasionale arena te kan kompeteer. Suid-Afrikaners het getoon dat hulle vir niemand hoef terug te staan as dit by uitvindings kom nie. Die tyd het egter nou vir die uitvinders aangebreek om ook innoveerders te wees.

C.W.I. PISTORIUS Instituut vir Tegnologiese Innovasie Universiteit van Pretoria 